\title{
Sciendo
}

Administration, vol. 69, no. 4 (2021), pp. 111-133

doi: 10.2478/admin-2021-0030

\section{Collaboratively planning climate action: What would it mean for Dublin? An analysis of the Clontarf flood defences}

\author{
Ali Grehan \\ Dublin City Council, Ireland
}

\section{Introduction}

Collaborative planning describes an engagement process between policymakers and citizens that aims to improve decision-making and create policies, projects and services that best meet collective needs. International and national climate policy emphasises that climate action is more likely to succeed if planned collaboratively between policymakers, citizens and other stakeholders, and local government has a key role in engaging with citizens to mobilise climate action. The United Nations Framework Convention on Climate Change (UNFCCC) Action for Climate Empowerment programme, which supports implementation of the 2015 Paris Agreement, sees citizens and policymakers creating mutual momentum towards more ambitious climate policy and action (UNFCCC, 2020). Ireland's Climate Action Plan to Tackle Climate Breakdown states: 'Local Authorities occupy a pivotal role in their respective local communities and can act to demonstrate public sector leadership on climate action in their areas as well as key mobilisers of action at a local and community level' (Government of Ireland, 2019, p. 127). Dublin City Council's (DCC) Climate Change Action Plan 2019-2024 (CAP) 
prioritises citizen engagement as one of four overarching goals, committing to 'actively inform and engage the public through a range of innovative programmes and partnerships and, where possible, facilitate bottom-up, community-led solutions' (Codema, 2019, p. 9).

Notwithstanding the CAP's focus on climate action, everything DCC does can be framed as climate action given its remit to develop Dublin sustainably. Similarly, all aspects of DCC work have a citizen engagement dimension, with much work subject to specific engagement processes. Questions can be asked about engagement effectiveness and whether engagement processes constitute collaborative planning given DCC often struggles to win support for sustainable place-making policies and projects. For example, how seriously does DCC take engagement? How representative are processes? Do outcomes reflect citizen input? DCC's capacity to mobilise climate action is also questionable given operational constraints. This paper answers these questions and recommends how DCC can redesign and revitalise engagement processes towards collaboratively planning climate action.

It does this through interviews with key personnel, a review of the expert literature on citizen engagement and how it can be understood as collaborative planning, and appraisal of engagement on a significant DCC climate adaptation project (the Clontarf Flood Defence (CFD) project) against this understanding.

Interviewees hold divergent views on DCC's capacity to engage citizens in climate action. Some point to organisational constraints; others consider DCC well placed given its proximity to citizens. Interviewees also hold divergent views on citizen engagement value generally. Some question citizen bona fides; others question DCC's openness to engagement. There is consensus that engagement processes need to be more effective but little clarity on how to do this.

It is evident from the literature that citizen engagement in itself does not constitute collaborative planning. Collaborative planning is conditional on engagement processes adhering to particular overlapping and interdependent guiding principles, proposed here as trust, openness, parity of esteem, effective communication and systems thinking. Collaborative planning is a complex area requiring skill and resources; there is no one-size-fits-all approach. Collaborative planning can deploy multiple engagement methods, which must be appropriate to context. Complex and challenging engagement contexts associated with climate action require deliberative methods. 
A key literature review finding is that inadequate engagement can undermine sustainable place-making and climate action. The CFD project validates this. DCC has spent fifteen years seeking to implement the project but has yet to agree a design approach with the community. Analysis of engagement from project initiation in 2005 to the end of 2020 finds shortcomings when appraised against collaborative planning principles. Inadequate early engagement has turned a critical climate adaptation project aimed at protecting vulnerable homes and businesses from coastal flooding into an ongoing conflict about loss of amenity. The CFD will transform the scenic Clontarf Promenade, therefore some citizen opposition is inevitable; however, a collaborative planning approach would have influenced how DCC approached the project, alerted DCC to issues earlier and saved time.

\section{DCC overview and climate action context}

DCC is a representative body and public service provider. Sixty-three councillors led by a lord mayor (the council) perform the representative role, with each councillor elected from, and representing citizens of, one of five city electoral areas. An administrative and technical body led by a chief executive (CE) delivers public services and reports to councillors at monthly council meetings. Quinlivan (2015) describes this arrangement as a 'Manager' or 'Partnership' model with decision-making power shared between council and CE. DCC's works programme encompasses public housing, public roads, surface water drainage and flood relief, planning and development, environmental protection, culture, recreation and amenity, and special initiatives. These have a combined value of $€ 2.6$ billion over three years (DCC, 2019) and are delivered through departments headed by assistant CEs. Ireland's National Adaptation Framework requires local authorities (LAs) to prepare climate adaptation strategies and to establish regional climate action regional offices (CAROs) to coordinate work (Department of Communications, Climate Action and Environment, 2018). DCC published its strategy in 2019. The CAP is coordinated by DCC's Environment and Transportation Department, supported by the CARO, with department heads responsible for actions in their programme area.

DCC's operational context affects its capacity to collaboratively plan climate action. Research by Ladner et al. (2016) indicates that 
Irish LAs have low levels of autonomy compared to those in other European countries, with decisions on operations and finance controlled by central government. Some programmes critical to Dublin's sustainable development are controlled by national bodies; for example, the National Transport Authority controls public transport; the Office of Public Works (OPW) is responsible for strategic flood risk management. Therefore, climate action requires strong alignment of priorities between DCC, central government and national bodies. An internal challenge is DCC's silo organisational structure, with each department having distinct areas of responsibility and decision-making power. This puts greater onus on the need to understand and appreciate collaborative planning value if DCC is to engage citizens effectively in climate action.

\section{DCC engagement vehicles}

Engaging with citizens and addressing citizen issues permeate council and executive interaction and programme delivery. Councillors engage with citizens through regular clinics and represent citizen concerns at monthly local area committee meetings and full council meetings. Local area offices coordinate delivery of services into communities and are a key interface between executive and councillors. Strategic policy committees (SPCs) offer an additional forum. These advise on policy formulation and include representatives from external organisations and interest groups in addition to councillors. The Local Government Reform Act, 2014, introduced public participation networks (PPN) to strengthen citizens' role in LA decision-making. The PPN gives community, social inclusion and environmental groups a vehicle for interaction with DCC and facilitates participation in decision-making structures such as SPCs, the statutory local community development committee, joint policing committees and other bodies. Comhairle na nÓg, a youth council network, gives children and young people the opportunity to influence policies.

Citizens have a statutory right to input into planning and development processes. The Planning and Development Act, 2000, specifies engagement timing and scope. Policy such as DCC's Development Plan requires engagement at various stages of plan formation. Statutory engagement on individual developments is limited to the planning application stage, when design proposals are at an advanced stage. Engagement beyond this is at each department's 
discretion. This varies. DCC's Housing Department routinely consults through non-statutory public meetings and establishes consultative fora involving community and resident representatives for larger regeneration programmes. An online Consultation Hub, introduced in 2013, has evolved into a portal for statutory and non-statutory engagement exercises. DCC's Environment and Transportation Department has used it to engage on Covid-19 mobility measures. Your Dublin, Your Voice is a public opinion panel that was established in 2010. It comprises 2,000 people selected through open invitation and shortlisted to ensure diversity of age, background and nationality. DCC also has multiple citizen engagement touchpoints through its libraries, arts and recreation services, and social inclusion programmes such as Age Friendly City.

DCC often uses interactive workshops instead of traditional public meetings. Some, such as Imagine College Green, are design-charrettebased events. DCC has also undertaken innovative engagement programmes; for example, Designing Dublin, The Studio, PIVOT Dublin initiatives such as Hidden Rooms and Framework, BETA Projects, the NEIC Art as Radical Hope process, and Smart Dublin. These are based on design thinking and often incorporate design charrettes. Notably, Designing Dublin was part of the CE's change agenda and aimed to teach DCC staff how to harness citizen creativity in co-designing regeneration concepts (Liedtka et al., 2013). Its legacy, The Studio, delivered the Dublinked open-data platform, which led to Smart Dublin, a collaboration between the four Dublin LAs. Smart Dublin is part of the DCC CE's department.

While citizen engagement is central to DCC's work as a public service provider and DCC has multiple vehicles through which it can engage with citizens, DCC interviewees in more senior positions are circumspect about DCC's capacity to mobilise citizens in climate action and the value of citizen engagement. This is born of negative experiences and the reality of dependence on central government. Interviewees responsible for climate action planning or involved in experimental initiatives are more optimistic about DCC capacity. There is consensus that engagement processes need to be more effective but little clarity on how to do this or what it means. Some see the cause lying outside DCC; for example, citizens' inability to act in the common good. Others see the cause lying within DCC; for example, unwillingness to allow engagement to influence decisionmaking. Some interviewees see climate action as an opportunity for DCC to adopt more creative approaches. 


\section{Understanding collaborative planning}

Engagement between policymakers and citizens on policies, projects and services towards sustainable place-making is often called 'collaborative planning' (AlWaer \& Cooper, 2020; Brand \& Gaffikin, 2007; Campion, 2018; Dekker, 2019; Healey, 1997; Linnenluecke et al., 2017; Roggema, 2014). Other terms used are 'creative participatory planning' (Cilliers \& Timmermans, 2014), 'participatory placemaking' (Ermacora \& Bullivant, 2016), 'participative design' (Landry, 2008; Singh \& Prakash, 2014) or simply 'public participation' (Berčič, 2015; Bryson et al., 2012; Rydin \& Natarajan, 2016; Sturzaker \& Shaw, 2015). This report uses the term 'collaborative planning'. Berčič (2015, p. 55) sees collaborative planning as 'two way communication and interaction' between citizens and policymakers 'with the overall goal of better decisions that are supported by the public'. Patsy Healey has written extensively about collaborative planning in urban policy and place-making in response to citizens' demand to influence decisions affecting their communities. Healey describes collaborative planning as an outcome of an approach, which is open to 'a range of stakeholders and how they would like to discuss issues', helps shape 'arenas where stakeholders meet', and 're-frame and re-structure their ways of proceeding' (Healey, 1997, p. 312). Planning for sustainability requires a transformational approach involving high levels of engagement and an outward-looking focus predicated on the belief sustainability is built on collaboration and cocreation with multiple (including non-traditional) stakeholders (Linnenluecke et al., 2017). This paper briefly reviews the literature on collaborative planning generally and with reference to place-making in order to guide a DCC approach to collaboratively planning climate action. It highlights the engagement methods appropriate to complex issues such as climate action, and proposes guiding principles to help determine whether citizen engagement processes constitute collaborative planning

\section{Engagement methods and approaches}

There are multiple engagement approaches and methods, deployed for different purposes, as documented, for example, by Participedia. ${ }^{1}$ While 'participation' and 'participative' are used as catch-all terms, these represent one overarching approach, the other being 
'deliberation' and 'deliberative' (Fishkin, 2009). As Fishkin (2009, p. 21) summarises, participative approaches elicit 'raw' opinions of a wide group of people, while deliberative approaches elicit 'refined' opinions of a narrow selection of people (Figure 1).

\section{Figure 1: Participative versus deliberative methods}

\begin{tabular}{|c|c|c|c|c|c|}
\hline & & \multicolumn{4}{|c|}{ Participant Selection Method } \\
\hline & $\begin{array}{l}\text { Quality of } \\
\text { Opinion } \\
\text { Generated }\end{array}$ & $\begin{array}{l}\text { 1. Self- } \\
\text { selection }\end{array}$ & $\begin{array}{l}\text { 2. Non- } \\
\text { random } \\
\text { sample }\end{array}$ & $\begin{array}{l}\text { 3. Random } \\
\text { sample }\end{array}$ & 4. "Everyone" \\
\hline Participative & A - 'Raw' & $\begin{array}{c}1 \mathrm{~A} \\
\text { Self-Selected } \\
\text { Listener } \\
\text { Opinion Poll }\end{array}$ & $\begin{array}{c}2 \mathrm{~A} \\
\text { Some Polls }\end{array}$ & $\begin{array}{c}3 \mathrm{~A} \\
\text { Most Polls }\end{array}$ & $\begin{array}{c}\text { 4A } \\
\text { Referendum } \\
\text { Democracy }\end{array}$ \\
\hline Deliberative & B - 'Refined' & $\begin{array}{c}1 \mathrm{~B} \\
\text { Discussion } \\
\text { Groups }\end{array}$ & $\begin{array}{c}\text { 2B } \\
\begin{array}{c}\text { Citizens Juries, } \\
\text { etc. }\end{array} \\
\end{array}$ & $\begin{array}{c}3 \mathrm{~B} \\
\text { Deliberative } \\
\text { Polls }\end{array}$ & $\begin{array}{c}\text { 4B } \\
\text { "Deliberation } \\
\text { Day" }\end{array}$ \\
\hline
\end{tabular}

Source: Fishkin (2009, p. 21, Chart 1).

Fung (2006) differentiates approaches by way of reach and intensity, from the focused deliberation of 'mini-publics' to wider participation with the 'macro-public' or society at large. His Democracy Cube locates engagement processes relative to participants, the form of interaction and the level of decision-making power afforded participants (Figure 2).

\section{Deliberative methods' value in climate action}

Deliberation is 'a particular sort of discussion - one that involves the careful and serious weighing of reasons for and against some proposition - or to an interior process by which an individual weighs reasons for and against courses of action' (Fearon, 1998, p. 63). Engaging on ambitious or complex issues such as 'higher quality plans and projects', 'healing fractured relationships' or 'building adaptive capacity for ongoing problem solving and resilience' requires deliberative approaches (Bryson et al., 2012, pp. 25-6). The literature offers arguments for this. Deliberation can help communities understand underlying complexity (Breeze et al., 2003). Even if consensus is not reached, deliberation can promote tolerance and understanding (Chambers, 2003). Face-to-face interaction is more effective than mass communication in encouraging behaviour change, negotiating conflicting values and 'visioning a common future' (Moser, 


\section{Figure 2: Democracy Cube}

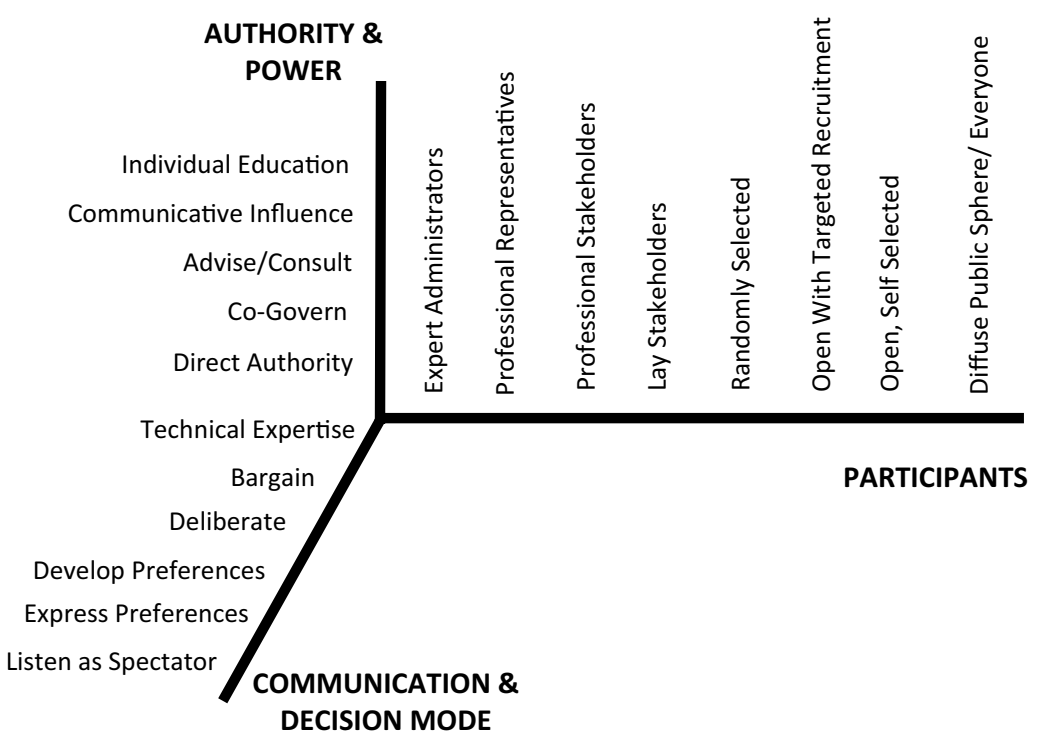

Source: Fung (2006, Fig. 4).

2010, p. 41). People solve problems and manage complexity better together; engagement relying on individually formulated responses are inadequate or crude (Chambers, 2018). Deliberation can counter the oversimplified and polarising nature of contemporary discourse amplified through multiple communication platforms, which can alienate reasonable citizens (Dryzek et al., 2019).

A deliberative approach can underpin various methods - for example, citizen juries, planning cells, deliberative polling, consensus conferences and citizen panels. While these follow different formats, they can be defined as deliberative given participants are provided with information, which they consider and discuss before making final recommendations (Abelson et al., 2003). Deliberative methods used in place-making include design charrettes, 'planning for real' and 'enquiry by design'. ${ }^{2}$ Campion describes the design charrette as:

members of the community working alongside local authorities and developers to co-create design-led, visual plans and strategies. It is an inspirational and energising activity where the 
results of collaboration are seen immediately, with the knowledge that each individual's input is listened to and actually matters. It also has the potential to speed up the formal design and planning process overall. (Campion, 2018, p. xv)

Design charrettes apply design thinking, defined by Cross (1982) as an approach to problem-solving derived from analysis of how good designers work. Design thinking approaches are iterative, co-creative, human-centred and structured in clear stages, as articulated, for example, in the Double Diamond Framework (Design Council, 2019). Design thinking is distinguished from other problem-solving approaches by understanding and reframing a problem around a shared value, which helps people define novel solutions and motivate people to move from polarised positions towards consensus (Dorst, 2011). Bryson et al. (2012, p. 24) connect design thinking approaches with public administration best practice: 'the difference is simply the heightened emphasis on purpose-driven, context-sensitive, holistic, user- and stakeholder-orientated, evidence-based designing and designs'. Vos (2014) advocates design thinking based on collaborative learning methods for engaging on complex issues such as climate action. With collaborative learning, engagement is energetic and participants are committed because 'work is done on real-world issues that participants experience as relevant to their context, combined with the freedom to contribute their best' (Vos, 2014, p. 52).

\section{Collaborative planning guiding principles}

The literature suggests that citizen engagement does not in itself constitute collaborative planning. For example, Healey (2003, p. 110) suggests that collaborative planning is born of 'comprehensibility, sincerity, legitimacy, truth, openness, inclusivity, reflexivity, and creativity' in engagement. This report proposes five interdependent principles that help define whether engagement processes constitute collaborative planning: trust, openness, parity of esteem, effective communication and systems thinking (Figure 3). The relevance of these principles in defining whether citizen engagement processes achieve collaborative planning is summarised as follows.

There is trust in the process and the process builds trust: policymakers and experts believe engagement is beneficial, are honest on the extent to which participants can influence issues, and invest resources in engagement. The process is open to multiple perspectives, including diverse and marginal views, with friction seen 
Figure 3: Collaborative planning principles

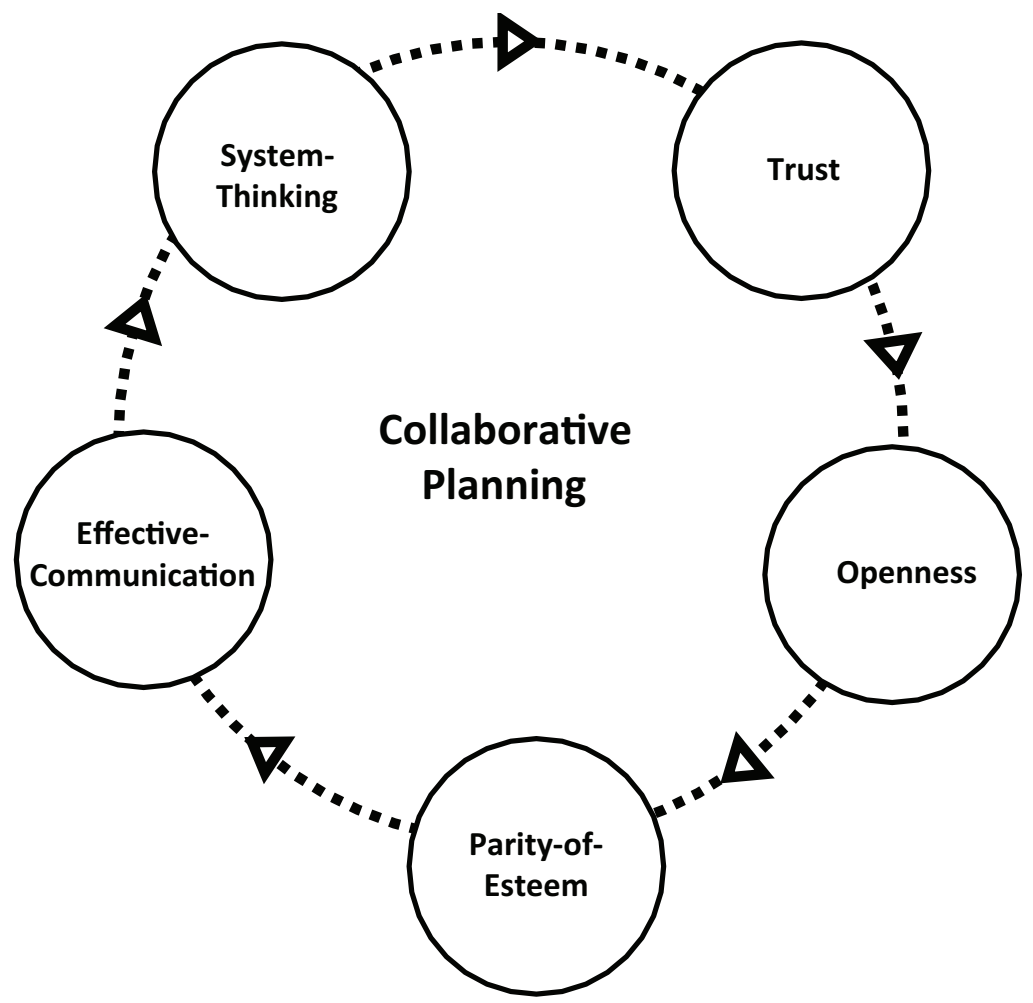

as positive. Policymakers, experts and citizens respect each other's knowledge and perspective. Policymakers and experts prioritise effective communication by making issues vivid, tangible and accessible for participants. Engagement events promote interaction and learning. Engagement processes are iterative, designed using a systems-thinking approach, which starts with understanding the engagement context. This informs issue definition, objectives, appropriateness of participants, and optimum methods, tools and techniques. Multiple engagement methods can be deployed in collaborative planning. Complex engagement contexts such as transformative climate action require deliberative methods. Collaborative planning can reduce NIMBYism, introduce new perspectives promoting innovation, and enrich all stages of a development process. Conversely, inadequate engagement can 
undermine sustainable place-making projects and climate action, erode trust between policymakers and citizens, and instil a sense of frustration in communities if they feel their views are not being taken seriously.

\section{The Clontarf flood defences}

Clontarf is a low-lying coastal suburb on Dublin City's north side. The area enjoys considerable public amenity, which is valued locally and makes Clontarf a recreation destination. A three-kilometre-long seafront park known as Clontarf Promenade enjoys views across Dublin Bay. A further two-kilometre stretch known as Dollymount Promenade runs between Saint Anne's Park and Bull Island nature reserve. The main road along Clontarf and Dollymount Promenades is a busy commuter route and forms part of the Sutton-to-Sandycove (S2S) cycleway (Figure 4). The area's low elevation relative to sea level makes it vulnerable to coastal flooding, with this vulnerability likely to increase due to climate-change-related sea level rise and extreme weather events. The Dollymount Promenade is also vulnerable to fluvial flooding from local rivers. A severe flood event in 2002 affecting several parts of Dublin prompted the OPW and DCC to plan a flood defence programme, which included defences for Clontarf and Dollymount Promenades.

Both the CFD and Dollymount Flood Defence (DFD) projects have been the subject of public controversy. The CFD has been the subject of protracted engagement between DCC and the community. Despite this, and the imperative to protect residents and businesses from escalating flood risk, DCC and the community have not agreed an acceptable design approach and the defence is yet to be constructed. DCC commissioned a design in 2005 and secured planning permission to construct a flood defence in 2008. However, the project was suspended in 2011 following public protests led by the Clontarf Residents' Association (CRA) and Clontarf Business Association (CBA). A mediated workshop in 2012 resulted in establishment of a Joint Working Group (JWG) comprising DCC and community representatives, which aimed to agree an acceptable design approach. The JWG remains in place as of December 2020 but has not reached consensus. Implementation of the DFD project was subsequent to, and affected by, the CFD controversy. DCC secured planning permission in 2013 to raise the existing flood wall along Dollymount Promenade as part of construction of the S2S. 
Figure 4: Clontarf location map, indicating key features

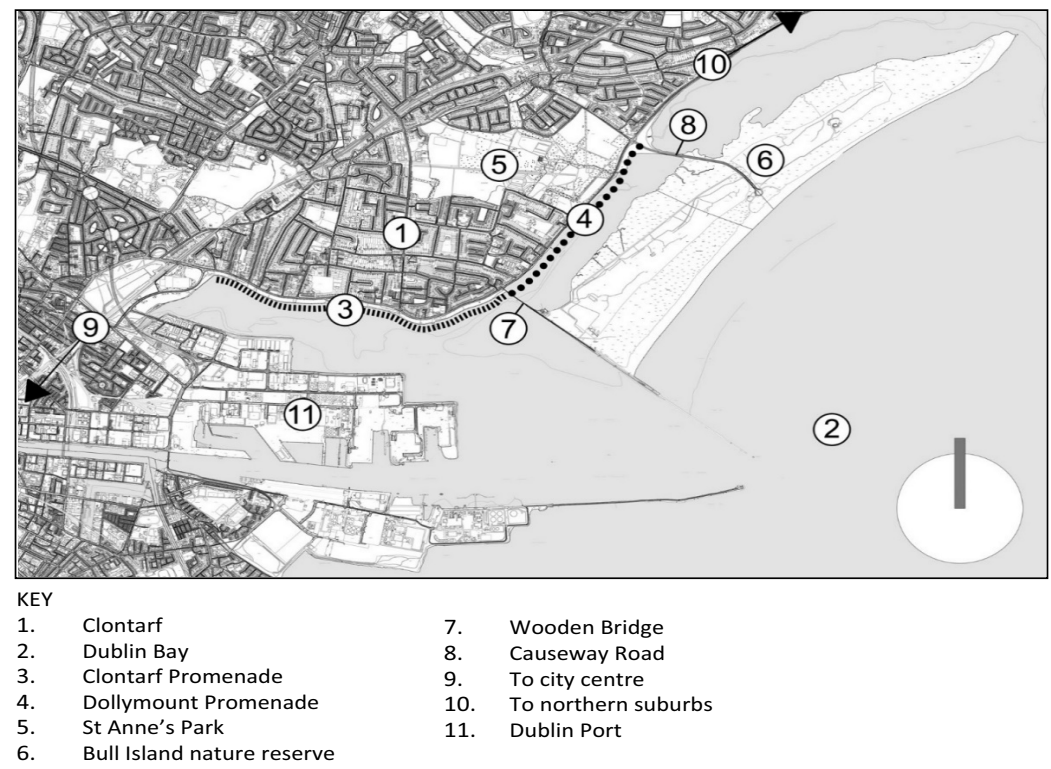

Base map (COSI. All rights reserved. License number 2020/23/CCMA/Dublin CityCouncil

Construction commenced a year later. Despite being significantly lower than the CFD proposal, and the CRA seemingly satisfied that 'DCC fully engaged with the CRA during the Part-8 process' (CRA \& CBA, 2015), the DFD drew criticism for its visual impact, including that it blocked motorists' views of the bay. Following independent review, DCC lowered the newly constructed DFD in 2018, rendering the defence inadequate. A timeline of key events is set out in Table 1.

Before reviewing aspects of CFD engagement, it is worth noting the broader context of flood defences in Ireland. The Climate Change Advisory Council (CCAC) identifies lack of an institutionally coordinated approach to coastal adaptation in Ireland as a key challenge for projects (CCAC, 2019). While the OPW is responsible for strategic flood risk management, responsibility for adaptation at local level rests with LAs, assisted by CAROs, while citizens and businesses also have responsibility for protecting their property (CCAC, 2019). DCC cannot proceed with the CFD without securing OPW approval and funding, which depends on defences meeting OPW design performance criteria. Another issue worth noting is 


\section{Table 1: Timeline of events - Clontarf and Dollymount Flood Defence projects}

2002 1 February: Flood event affects Clontarf and other Dublin coastal areas. DCC commissions flood experts to undertake strategic assessment of coastal flood risk.

2005 Dublin Coastal Flooding Protection Project Strategic Assessment completed. It contains five options for CFD, recommending one. DCC adds CFD to existing contract to design a new arterial water main along Clontarf Promenade.

200728 November: DCC submits CFD to An Bord Pleanála (ABP) under title North City Arterial Water Main - Fairview to Baldoyle: Clontarf Coastal Flood Protection project and undertakes statutory consultation.

2008 July: ABP grants planning permission for CFD with no third-party objections.

2011 October: DCC meets local business owners to discuss parking disruption due to imminent construction of CFD and are questioned about CFD height.

$11 \& 12$ October: CRA/CBA initiate a campaign against CFD and exhibit DCC's proposal.

16 October: Approximately 5,000 people, including public representatives, gather on Clontarf Promenade to protest against the CFD proposal.

4 November: DCC modifies proposal and meets CRA/CBA to review. CRA/CBA reject modifications as do not go far enough to meet community requirements.

7 November: Council meeting. Councillors reject CFD, directing DCC to modify proposal further, engage with community and report outcomes at next meeting.

16, 17, 19 \& 23 November: DCC holds public information sessions in Clontarf Castle Hotel. CRA/CBA hold parallel sessions, presenting alternative proposal. Over 2,000 people attend; DCC receives approximately 4,000 submissions.

5 December: DCC reports to councillors at monthly council meeting. Report details CFD project background, engagement at planning and outcome of recent public information sessions. Councillors reject modified proposal and direct DCC to redesign the CFD in consultation with the community.

2012 October: CRA/CBA survey local residents and businesses and gather 961 responses. 


\section{Table 1: Timeline of events - Clontarf and Dollymount Flood Defence projects (Contd.)}

\begin{tabular}{|c|c|}
\hline & $\begin{array}{l}23 \text { October: DCC officials and consultants, CRA, CBA and public } \\
\text { representatives attend facilitated, deliberative workshop to agree a } \\
\text { strategy for a revised scheme. Participants agree to establish JWG. } \\
14 \text { December: DCC submits DFD for planning under a Part } 8 \\
\text { process. }\end{array}$ \\
\hline \multirow[t]{4}{*}{2013} & $\begin{array}{l}15 \text { January: CRA hosts DFD public meeting, attended by } 180 \\
\text { people. }\end{array}$ \\
\hline & $\begin{array}{l}21 \text { February: JWG holds first meeting. Seven more meetings held in } \\
2013 \text {. }\end{array}$ \\
\hline & 23 April \& 10 May: DCC holds on-site public meetings for DFD. \\
\hline & 13 May: Councillors grant planning permission for DFD. \\
\hline 2014 & JWG meets twice. \\
\hline \multirow[t]{2}{*}{2015} & $\begin{array}{l}11 \text { November: Councillors direct DCC to commission independent } \\
\text { expert review of DFD in response to public complaints. }\end{array}$ \\
\hline & JWG meets once. \\
\hline 2016 & JWG meets twice. \\
\hline \multirow[t]{2}{*}{2017} & $\begin{array}{l}\text { 14 June: DCC submits planning application to lower DFD wall and } \\
\text { clad it in stone, as recommended by independent review. }\end{array}$ \\
\hline & JWG meets twice. \\
\hline \multirow[t]{2}{*}{2018} & $\begin{array}{l}8 \text { January: Councillors approve DFD modification works to lower } \\
\text { flood defence. }\end{array}$ \\
\hline & JWG meets twice. \\
\hline 2019 & JWG meets three times. \\
\hline 2020 & $\begin{array}{l}\text { JWG meets twice, bringing number of meetings to twenty-two since } \\
\text { JWG inception. }\end{array}$ \\
\hline
\end{tabular}

citizen perception of flood risk, a factor in CFD engagement. Bradford et al.'s (2012) study of thirteen communities across Europe who are exposed to flooding found little correlation between concern about flooding and willingness to act, with Irish communities believing responsibility for flood management lies with LAs, not property owners. Pilla et al.'s (2019) study of how flood risk affects Dublin residential property values found that while past flooding impacts negatively on buyer behaviour, future flood risk projections have little impact.

The remit of this paper, and the research on which it is based, is not to suggest next steps for CFD engagement but to suggest what DCC might learn from the process. 


\section{Key learnings}

The appraisal of CFD engagement processes is based on interviews with DCC personnel, councillors and a community member involved in the project, in addition to a review of the project timeline. The emerging narrative is assessed against collaborative planning principles and suggests the following key learnings.

\section{Trust}

Trust as a basis for, and outcome of, engagement is fundamentally important in collaborative planning. Critically, engagement should be motivated by belief that the process will benefit the project and result in better outcomes. AlWaer \& Cooper (2020, p. 3) describe this as 'building common purpose'. Evaluation of the CFD against Hurlbert \& Gupta's (2015) Split Ladder indicates that the flood defence issue was a moderately structured problem in that there was some agreement on problem and solution. However, inadequate engagement at early stages, in particular at planning application stage, turned the CFD into an unstructured problem characterised by distrust where consensus might not be possible (Hurlbert \& Gupta, 2015). At risk of seeming to make light of this serious issue, the one area of agreement between community and DCC is that neither seems to trust the other's motivations. On a practical level, loss of trust has prolonged the project and cost time and money. It has also contaminated the DFD project. It is questionable whether the DFD would have generated criticism in absence of the CFD controversy.

\section{Openness}

Collaborative planning requires openness in engagement - openness to creativity, innovation, friction and multiple perspectives. Implicit in this is that engagement processes should be open to, and representative of, affected communities and stakeholders. DCC's initial treatment of the CFD as a purely technical engineering issue was a significant factor in 2011 community opposition. Since then, a key community ask is for DCC to adopt a multidisciplinary creative approach to designing the defence. Against this, DCC's overwhelming criteria are keeping the project within budget limits. While 2011 interaction between DCC and the community was fiercely adversarial ('as bad an issue as I've seen, up until then or since then', according to one community representative), JWG interaction has settled into a 'benign, low-level kind of frustration'. A key problem now is fear of friction and community backlash if and when DCC presents a new 
design to the public. Perception that engagement is not representative dominates DCC thinking, particularly perception that opinions of residents most vulnerable to flooding are not being heard.

\section{Parity of esteem}

Engagement on complex issues requires people to work collaboratively and accept there is no single point of expertise or single right answer. Therefore, interaction between experts and citizens demands parity of esteem, with each recognising the value of the other's viewpoint and contribution. Related to this is the issue of place attachment - that is, individual and collective ownership of a place. Expert facilitation of engagement processes can help ensure parity of esteem. In the case of the CFD, failure to engage with the community in design brief definition meant DCC did not appreciate context sensitivity, place attachment and the need for a multidisciplinary place-making approach. A necessary endeavour to protect a community from flooding has become a conflict about loss of amenity. On DCC's part, there is frustration that the community does not seem to appreciate DCC's expertise in flood risk and defence design, as well as community ambivalence to flood risk.

\section{Effective communication}

How issues are communicated, and how communication is managed within processes, influences participants' capacity to contribute and the quality of that contribution. This indicates the need for effective communication in engagement. With the CFD, councillors and the community did not understand DCC's planning application drawings, which were technical, so did not object, leading DCC to believe that the community supported the project. This also enabled the community to produce seemingly credible alternative design solutions, as they were visually accessible and compelling. While better communication by DCC might have caused the community to object at planning application stage, it would have alerted DCC to challenges earlier. Community representatives acknowledged that DCC made significant efforts to explain the project rational and modify the design following the 2011 protests; however, DCC had lost control of communication by then.

\section{Systems thinking}

Collaborative planning requires a systems thinking approach using multiple methods (Chambers, 2018). Citizen engagement must be 
integral to the project and tailored to project context (Bryson et al., 2012). It is clear that DCC did not devise an engagement strategy at project outset that went beyond statutory public engagement at planning application stage and briefings for local councillors. While various engagement methods have been deployed by both DCC and the community (opinion poll, public exhibition, public meetings, facilitated workshop, JWG process), they appear to be reactive and stand-alone rather than part of a holistic strategy. This also begs the question whether DCC has taken engagement seriously. For example, the 2012 facilitated workshop was productive but JWG interaction has not built on workshop outcomes. The JWG is at an impasse but independent facilitation has not been introduced to enable progress. Furthermore, despite DCC belief that the CFD failed because of NIMBYism and that the JWG is not representative, DCC has allowed the JWG to continue for eight years instead of changing approaches to address these issues.

\section{Conclusions and recommendations}

This paper starts from the premise that climate action measures are more likely to succeed if planned collaboratively between citizens and policymakers, and that local government has a key role in engaging with citizens to mobilise climate action. This premise is emphasised in policy supporting implementation of the Paris Agreement, and citizen engagement is prioritised in DCC's CAP. Citizen engagement is already intrinsic to DCC work and DCC invests significant time in engagement. However, DCC interviewees are frustrated with engagement processes and ambivalent about citizen engagement value. DCC efforts to construct flood defences in the Dublin coastal suburb of Clontarf illustrates this. The CFD is a critical climate adaptation project for Dublin. DCC has spent fifteen years seeking to implement the project but has yet to agree a design approach with the community. While the CFD project is an extreme example, DCC often struggles to win public support for important place-making projects. It is not certain that better citizen engagement would cause communities to embrace sustainable but transformative place-making projects; however, in the CFD case, DCC would have likely reached the point it is at now earlier. In other words, collaborative planning would have saved time.

The transformative change demanded in climate action requires trust between citizens and policymakers. This report finds that 
collaborative planning can create trust while poorly executed engagement can undermine trust, and therefore sustainable placemaking and climate action efforts. Time is not on DCC's side when it comes to climate action. In view of the CAP commitment to engage, or collaboratively plan climate action, with citizens and the imperative to address climate change, DCC must change its attitude and approach to engagement.

To avoid wasting time, DCC's attitude to engagement must change to one that accepts internal knowledge limitations, values creative thinking as intrinsic to place-making, welcomes external perspectives and views citizens as an asset. The attitude must be embedded across DCC - in its culture, working processes and procedures, and delivery of projects - and requires top-down leadership and appreciation within teams. DCC engagement approaches must be better coordinated and based on systems thinking. The following recommendations set out steps towards achieving this.

\section{Recommendation 1: Legitimise collaborative planning within DCC}

- Collaborative planning requires skill and resources.

- DCC to assign resources to developing a corporate understanding and approach to collaborative planning, including procurement of expert consultants.

- An internal project team to be established to develop the approach with the expert consultant (the Team), reporting to the CE to assist legitimacy.

Recommendation 2: Compile an inventory of current and recent citizen engagement vehicles to establish range of vehicles available to DCC

- There is no central record of engagement vehicles available to DCC.

- Team to compile an inventory of current and recent vehicles.

- Inventory to include process name and description; method, i.e. participative or deliberative; whether statutory or non-statutory; routine or 'one-off'; process 'owner', i.e. department responsible for initiating and leading process; and other relevant information - for example, timescale, number of participants, etc.

\section{Recommendation 3: Undertake a qualitative analysis of engagement vehicles in use \\ - Team to evaluate a representative sample of vehicles against collaborative planning principles.}


- The purpose is to gain a better understanding of why and how DCC applies engagement, not to appraise every vehicle.

- Appraisal should be project focused and reach conclusions on process strengths and weaknesses.

- Analysis should include one project from each DCC department section.

- Models in collaborative planning literature and questions in Figure 5 could inform appraisal.

Figure 5: Questions to inform qualitative appraisal of DCC engagement vehicles

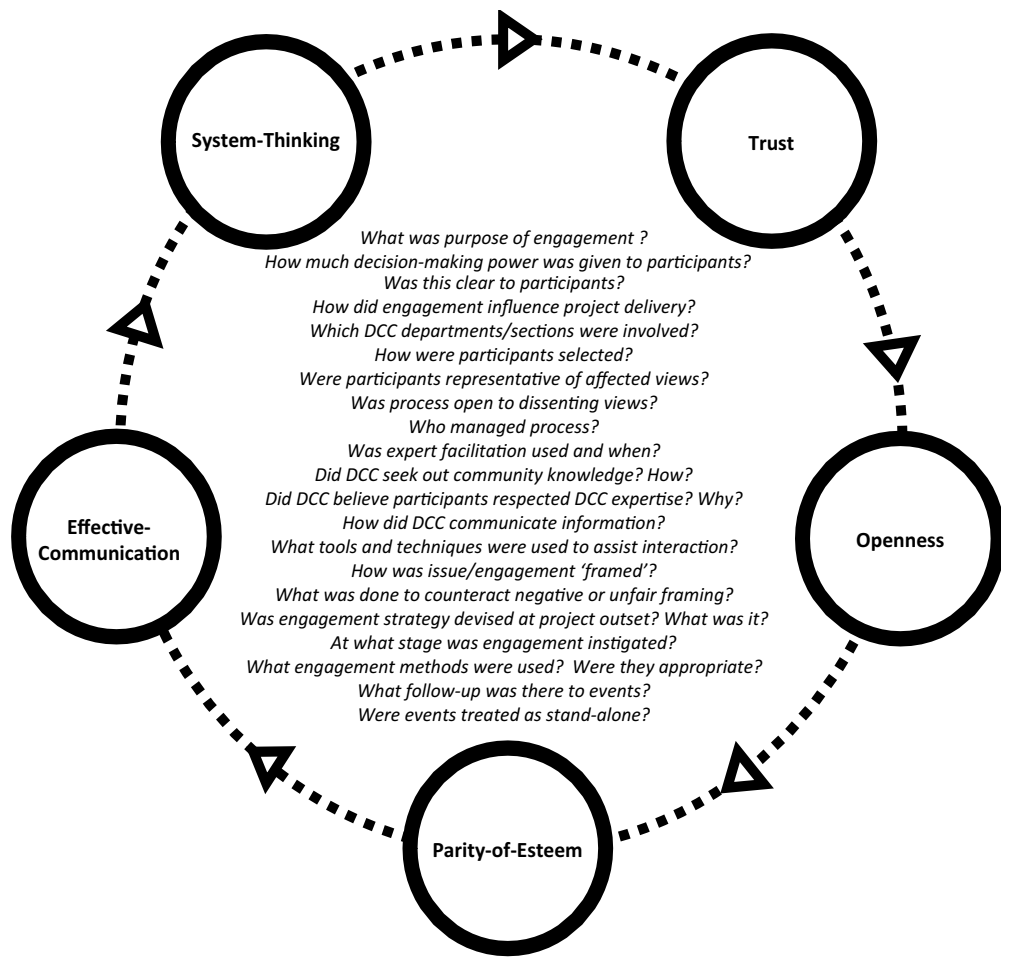

Recommendation 4: Develop a DCC-specific collaborative planning model

- Team to develop a collaborative planning process model aligned with project delivery.

- Model would have the following key phases: (1) establish engagement purpose and context; (2) establish process legitimacy; 
(3) manage engagement process; and (4) maintain accountability and transparency. A high-level model is illustrated in Figure 6.

Figure 6: Proposed DCC collaborative planning model

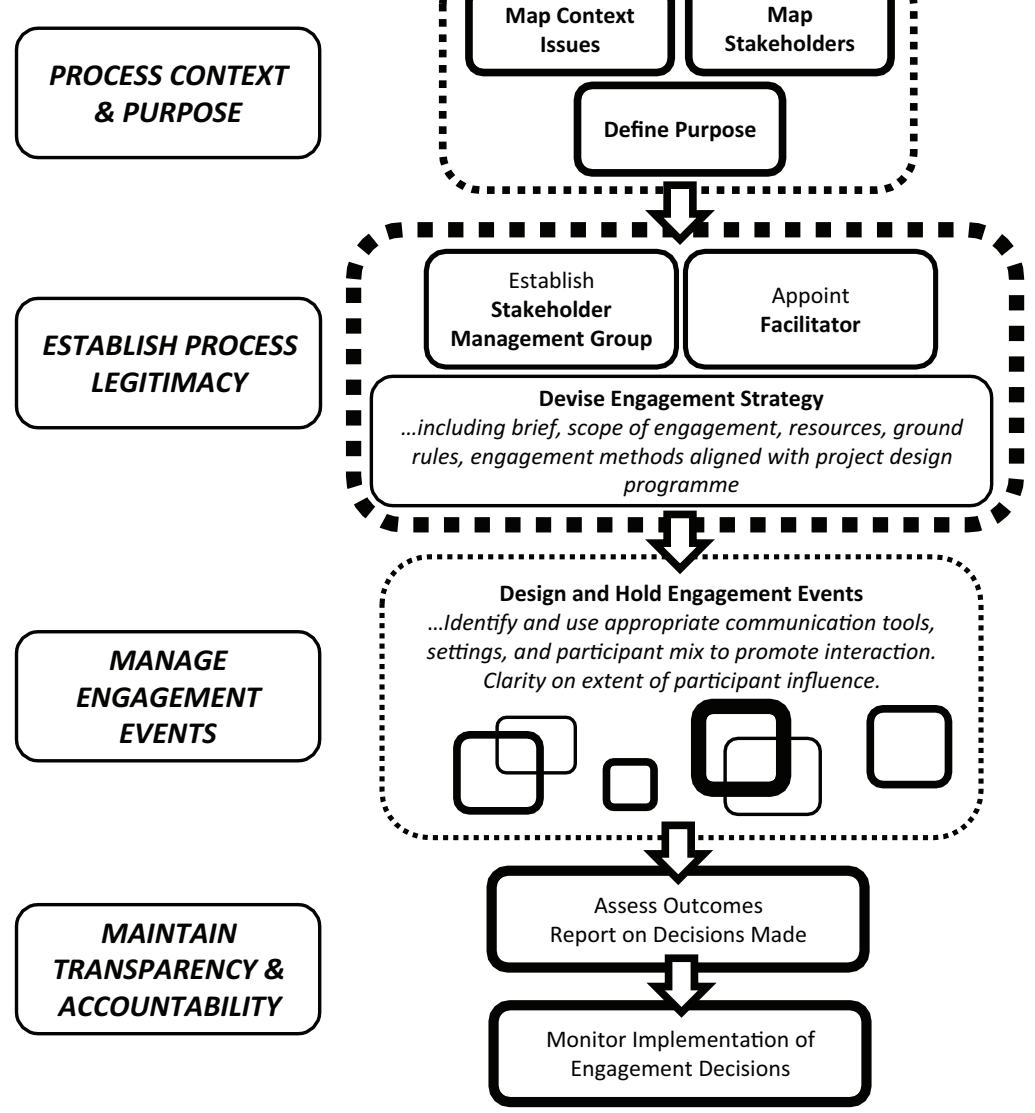

Recommendation 5: Test and refine DCC model through selected pilot projects

- Apply model to two or three selected projects, each from a different DCC department.

- Team and department heads to monitor process.

- Team to refine model based on project learnings and develop a detailed engagement handbook and toolkit.

- Review and re-issue handbook and toolkit every five years. 


\section{References}

Abelson, J., Pierre-Gerlier, F., Eyles, J., Smith, P., Martin, E., \& Gauvin, F. (2003). Deliberations about deliberative methods: Issues in the design and evaluation of public participation processes. Social Science \& Medicine, 57 (2), 239-51. doi: 10.1016/S0277-9536(02)00343-X

AlWaer, H., \& Cooper, I. (2020). Changing the focus: Viewing design-led events within collaborative planning. Sustainability, 12 (8), 3365. doi: $10.3390 / \mathrm{su} 12083365$

Berčič, J. (2015). The state of public participation in spatial planning in the European Union: public participation in spatial planning between theory and practice. The Creativity Game: Theory and Practice of Spatial Planning, 3, 54-61. doi: 10.15292/IU-CG.2015.03.054-061

Bradford, R., O’Sullivan, J., \& van der Craats, M. (2012). Risk perception Issues for flood management in Europe. Natural Hazards and Earth System Sciences, 12, 2299-2309. doi: 10.5194/nhess-12-2299-2012

Brand, R., \& Gaffikin, F. (2007). Collaborative planning in an uncollaborative world. Planning Theory, 6 (3), 282-313. doi: 10.1177/1473095207082036

Breeze, J., Turner, R., \& Patterson, P. (2003). Anti community behaviour: Ballymun Citizens' Jury report $3^{\text {rd }}$-8th April 2003. Dublin: Vision 21.

Bryson, J. M., Quick, K., Schively Slotterback, C., \& Crosby, B. (2012). Designing public participation processes. Public Administration Review, 73 (1), 23-34. doi: 10.1111/j.1540-6210.2012.02678.x

Campion, C. (2018). 20/20 visions: Collaborative planning and placemaking. London: RIBA Publishing.

Chambers, S. (2003). Deliberative democratic theory. Annual Review of Political Science, 6 (1), 307-26. doi: 10.1146/annurev.polisci. 6.121901.085538

Chambers, S. (2018). Human life is group life: Deliberative democracy for realists. Critical Review, 30 (1-2), 36-48. doi: 10.1080/08913811. 2018.1466852

Cilliers, E. J., \& Timmermans, W. (2014). The importance of creative participatory planning in the public place-making process. Environment and Planning B - Planning \& Design, 41 (3), 413-29. doi: 10.1068/b39098

Climate Change Advisory Council. (2019). Climate Change Advisory Council annual review 2019. Retrieved from http://www.climatecouncil.ie/council publications/annualreviewandreport/ [24 June 2020].

Clontarf Residents' Association \& Clontarf Business Association. (2015). Information from DCC regarding sea wall. Retrieved from https://www.loveclontarf.ie/news/information-from-dcc-regarding-sea-wall/ [27 October 2020].

Codema. (2019). Dublin City Council climate change action plan 2019-2024. Dublin: Dublin City Council.

Cross, N. (1982). Designerly ways of knowing. Design Studies, 3 (4), 221-7. doi: 10.1016/0142-694X(82)90040-0 
Dekker, S. (2019). Cities leading climate action: Urban policy and planning. New York: Routledge.

Department of Communications, Climate Action and Environment. (2018). National adaptation framework: Planning for a climate resilient Ireland. Dublin: Department of Communications, Climate Action and Environment.

Design Council. (2019). What is the framework for innovation? Design Council's evolved double diamond. Retrieved from https://www.designcouncil.org.uk/ news-opinion/what-framework-innovation-design-councils-evolveddouble-diamond [17 August 2020].

Dorst, K. (2011). The core of 'design thinking' and its application. Design Studies, 32 (6), 521-32. doi: 10.1016/j.destud.2011.07.006

Dryzek, J. S., Bächtiger, A., Chambers, S., Cohen, J., Druckman, J. N., Felicetti, A., ... Warren, M. E. (2019). The crisis of democracy and the science of deliberation. Science, 363 (6432), 1144-6. doi: 10.1126/science.aaw2694

Dublin City Council. (2019). Dublin City Council capital programme 2020-2022. Dublin: Dublin City Council.

Ermacora, T., \& Bullivant, L. (2016). Recoded city: Co-creating urban futures. Abingdon: Routledge.

Fearon, J. D. (1998). Deliberation as discussion. In J. Elster (Ed.), Deliberative democracy (pp. 44-68). Cambridge: Cambridge University Press. doi: 10.1017/CBO9781139175005.004

Fishkin, J. (2009) When the people speak: Deliberative democracy and public consultation. Oxford: Oxford University Press.

Fung, A. (2006). Varieties of participation in complex governance. Public Administration Review, 66, 66-75.

Government of Ireland. (2019). Climate action plan to tackle climate breakdown. Retrieved from https://www.dccae.gov.ie/en-ie/climateaction/topics/climate-action-plan/Pages/climate-action.aspx [14 July 2020].

Healey, P. (1997). Collaborative planning: Shaping places in fragmented societies (2nd ed.). London: Palgrave MacMillan.

Healey, P. (2003). Collaborative planning in perspective. Planning Theory, 2 (2), 101-23. doi: 10.1177/14730952030022002

Hurlbert, M., \& Gupta, J. (2015). The split ladder of participation: A diagnostic, strategic, and evaluation tool to assess when participation is necessary. Environmental Science \& Policy, 50, 100-113. doi: 10.1016/j.envsci.2015.01.011

Ladner, A., Keuffer, N., \& Baldersheim, H. (2016). Measuring local autonomy in 39 countries (1990-2014). Regional \& Federal Studies, 26, 321-57. doi: $10.1080 / 13597566.2016 .1214911$

Landry, C. (2008). The creative city: A toolkit for urban innovators (2nd ed.). London: Earthscan.

Liedtka, J., King, A., \& Bennett, K. (2013). Solving problems with design thinking: Ten stories of what works. New York: Columbia Business School Publishing. 
Linnenluecke, M. K., Verreynne, M.-L., de Villiers Scheepers, M. J., \& Venter, C. (2017). A review of collaborative planning approaches for transformative change towards a sustainable future. Journal of Cleaner Production, 142, 3212-24. doi: 10.1016/j.jclepro.2016.10.148

Moser, S. C. (2010). Communicating climate change: History, challenges, process and future directions. WIREs Climate Change, 1 (1), 31-53. doi: 10.1002/wcc. 11

Pilla, F., Gharbia, S. S., \& Lyons, R. (2019). How do households perceive flood-risk? The impact of flooding on the cost of accommodation in Dublin, Ireland. Science of The Total Environment, 650, 144-54. doi: 10.1016/j.scitotenv.2018.08.439

Quinlivan, A. (2015). The development of the Irish management system and the move towards directly elected mayors. Administration, 63 (2), 101-17. doi: 10.1515/admin-2015-0012

Roggema, R. (Ed.) (2014). The design charrette: Ways to envision sustainable futures. New York: Springer Science \& Business Media.

Rydin, Y., \& Natarajan, L. (2016). The materiality of public participation: The case of community consultation on spatial planning for north Northamptonshire, England. Local Environment, 21 (10), 1243-1251. doi: 10.1080/13549839.2015.1095718

Singh, V., \& Prakash, S. (2014). Lok Jumbish: Rural participatory design in Rajasthan, lessons for the future. In R. Roggema (Ed.), The design charrette: Ways to envision sustainable futures (pp. 151-66). New York: Springer Science \& Business Media.

Sturzaker, J., \& Shaw, D. (2015). Localism in practice: Lessons from a pioneer neighbourhood plan in England. The Town Planning Review; Liverpool, 86 (5), 587-609. doi: http://dx.doi.org.dcu.idm.oclc.org/10.3828/tpr.2015.34

UNFCCC. (2020). What is action for climate empowerment? Retrieved from https:/unfccc.int/topics/education-youth/the-big-picture/what-is-actionfor-climate-empowerment [12 July 2020].

Vos, L. (2014). Innovations in organisational and community learning. In R. Roggema (Ed.), The design charrette: Ways to envision sustainable futures (pp. 35-59). New York: Springer Science \& Business Media. 